\title{
Kimberlites of Camsell Lake field and some features of construction, and composition of lithosphere roots of southeastern part of Slave Craton, Canada
}

Pokhilenko', N.P., McDonald $^{2}$, J.A., Melnyk ${ }^{2}$, W., Hall ${ }^{2}$, A.E., Shimizu ${ }^{3}$, N., Vavilov ${ }^{1}$, M.A., Afanasiev', V.P., Reimers ${ }^{1}$, L.F., Irvin ${ }^{2}$, J., Pokhilenko', L.N., Vasilenko', V.B., Kuligin', S.S., and Sobolev ${ }^{1}$, N.V.

1. Institute of Mineralogy and Petrography, Siberian Branch of Russian Academy of Sciences, Novosibirsk, 630090, Russia

2. Winspear Resources Ltd., Vancouver, Canada

3. Department of Geology and Geophysics, Woods Hole Oceanographic Institution, Woods Hole, MA 02543, USA

Since the discovery of the first kimberlite pipe CL-25 within a new kimberlite field situated east of Camsell Lake in 1994 (Pokhilenko et al., 1995, 1997), Winspear Resources Ltd. has recognized a number of new bodies: the CL-174 Pipe few hundreds of meters apart from the CL-25 Pipe, a system of dikes, and a blind body filled with a breccia of complex composition near Snap Lake about $20 \mathrm{~km}$ west of the CL-25 and CL-174 pipes.

Petrographic and petrochemical characteristics of the CL-25 and CL-174 kimberlites are very close; the distribution patterns of compositions of garnets, magnesian ilmenites, and $\mathrm{Cr}$-spinellide from both pipes are also quite identical. All the characteristics of kimberlites and their mantle-derived minerals reported for the CL-25 Pipe (Pokhilenko et al., 1995, 1997) may be valid for the CL-174 Pipe as well. It is made up of typical kimberlite breccia with a high content of xenogenous material represented chiefly by the host granitoids and metamorphic rocks. Petrochemical and petrographical characteristics of the kimberlites from the CL-174 Pipe also permit them to be classified as group I (Skinner, Clement, 1979). Like the CL-25 Pipe, this pipe is poor in diamonds.

The kimberlite rocks found in a system of dikes and in boulder trains near Snap Lake drastically differ from the kimberlites from the CL-25 and CL-174 pipes in petrography, petrochemistry, mineralogy, and in being incomparably richer in diamonds. The kimberlites from the Snap Lake region are established in a series of dikes up to $4 \mathrm{~m}$ thick, drilled on the western shore of the lake, in its southern part. Also, they are found in a blind body, resembling a thick (about $100 \mathrm{~m}$ ) sill, drilled at a depth of $100 \mathrm{~m}$; this body is made up of compositionally complex breccia with an upward variable amount of kimberlite material, reaching the maximum in the lower part of the body. A great deal of kimberlite fragments (hundreds of kilograms) have been established in a boulder train, extended from Snap Lake through a peninsula in the southern part of the lake.

The dikes of the western shore are made up of kimberlite rocks with the massive texture of the groundmass and virtually contain no host rock xenoliths; the mantle rock xenoliths are very rare and are represented chiefly by serpentinized granular peridotites. Grains of pyropes, mainly of purple color and up to $3 \mathrm{~mm}$ in size, are very scarce. Grains of octahedral chromites up to $1.5 \mathrm{~mm}$ in size are also rare. Ilmenites in the rock are not found at all. It was established that the crushed and panned specimen, composed of several ten small fragments of $1.1 \mathrm{~kg}$ in total weight, contained 11 grains of pyrope, 16 grains of chromite, and 4 grains of diamond, the largest of which was about 2 $\mathrm{mm}$ in size. In composition these rocks belong to the most magnesian varieties of kimberlites and have analogs among the Siberian diamond-rich kimberlites: $31.6-32.4 \mathrm{wt} . \% \mathrm{SiO}_{2}, 0.73-0.83 \mathrm{wt} . \%$ $\mathrm{TiO}_{2}, 3.18$ - 3.93 wt. $\% \mathrm{Al}_{2} \mathrm{O}_{3}, 8.61-9.38$ wt. $\% \mathrm{Fe}_{2} \mathrm{O}_{3}, 0.18-0.23$ wt.\% $\mathrm{MnO}, 32.5-33.7$ wt. $\%$ $\mathrm{MgO}, 1.64-5.39$ wt. $\% \mathrm{CaO}, 0.01-0.15$ wt. $\% \mathrm{Na}_{2} \mathrm{O}, 0.36-0.58$ wt. $\% \mathrm{~K}_{2} \mathrm{O}, 0.50-0.82$ wt. $\%$ $\mathrm{P}_{2} \mathrm{O}_{5} ; \mathrm{LOI}=13.2-15.9$ wt. $\%$.

The pyropes from kimberlites have an unusually wide range of variations in $\mathrm{Cr}_{2} \mathrm{O}_{3}$ contents, up to $17 \mathrm{wt} . \%$, and this distinguishes them from the pyropes from the South-African and Siberian pipes, 
where, in commensurate samples (200-250 grains), the maximum contents of $\mathrm{Cr}_{2} \mathrm{O}_{3}$ do not exceed 10-11 wt.\% and 11-12 wt.\%, respectively. A very interesting feature of the pyropes, very rich in $\mathrm{Cr}_{2} \mathrm{O}_{3}(>12 \mathrm{wt} . \%)$ is an REE distribution pattern, not typical of standard pyropes of lherzolite paragenesis, similar to the S-type REE signature for the diamond-coexistent subcalcium pyropes of harzburgite-dunite paragenesis (Shimizu, Richardson, 1987; Pokhilenko et al., 1993), whose content in the sample investigated is comparatively low $(\sim 6 \%)$.

The $\mathrm{Cr}$-spinellide from the kimberlites of the western region of Snap Lake have a high proportion of Cr-rich (>60 wt. $\%$ ) compositions - about 30\%, more than $17 \%$ of them having characteristics of diamond-coexisting chromites (Sobolev et al., 1975). The kimberlite fragments from the southern boulder trace in the region around Snap Lake drastically differ from the above-described rocks in the western part in having a considerable amount of xenogenous material represented by fragments of the host and mantle-derived rocks. Their chemical composition is more diverse, with its primary characteristics being displaced, for most specimens, by secondary quartzing processes. The freshest specimens show wider ranges of variations in $\mathrm{CaO}$ contents - up to $9 \mathrm{wt} . \%$; an elevated amount of xenogenous material is reflected in elevated contents of $\mathrm{SiO}_{2}$ (up to 39 wt.\%) and $\mathrm{Al}_{2} \mathrm{O}_{3}$ (up to $6 \mathrm{wt. \% ).} \mathrm{Up} \mathrm{to} \mathrm{three} \mathrm{rock} \mathrm{varieties,} \mathrm{including} \mathrm{the} \mathrm{dike} \mathrm{type,} \mathrm{may} \mathrm{be} \mathrm{recognized} \mathrm{according} \mathrm{to}$ petrographic features in the kimberlites from the southern boulder train. At the same time, there are fragments with kimberlite-in-kimberlite inclusions, typical of the rocks from pipe-like bodies.

The kimberlites from the southern boulder train contain much more pyropes. The pyropes are up to $2 \mathrm{~cm}$ in size and, as a rule, have a thick kelyphytic rim $(0.5-1.5 \mathrm{~mm})$; the biggest grains are of orange color, typical of the pyropes of megacryst series. Chromite crystals of predominantly octahedral shape are quite abundant in the rock.

Common signatures of the pyropes and chromites from the southern kimberlites are similar to those for the kimberlites from the western segment of the area, but there are significant inhomogeneities in the signatures of the pyropes whose representative specimens were taken from separate localities of the boulder train. Along with petrographic characteristics, this is evidence either of multiple primary sources of the train or polyphase nature of one huge source. The content of subcalcium pyropes ( $>5 \mathrm{wt} . \% \mathrm{Cr}_{2} \mathrm{O}_{3}$ ) varies here from 1 to $4 \%$ indifferent specimens.

The diamonds of 0.2 to $3.5 \mathrm{~mm}$ in size are represented by a morphological set typical of kimberlites. Most grains are crystal fragments; among the unbroken crystals there are octahedrons, spinel twins, tetrahexahedrons, and cubes. The population of crystals of size $<1 \mathrm{~mm}$ have significant proportion of yellow cubes and their fragments.

Analysis of specific features of composition and paragenesis of the pyropes and chromites from the Snap Lake kimberlites indicates that there exists the thick lithosphere $(\sim 300 \mathrm{~km})$, whose roots are made up of depleted lherzolites with very high $\mathrm{Cr} /(\mathrm{Cr}+\mathrm{Al})$. Geochemical characteristics of the most $\mathrm{Cr}$-rich garnets $\left(\mathrm{Cr}_{2} \mathrm{O}_{3}>12 \mathrm{wt} . \%\right)$, in particular $\mathrm{REE}$ signature along with high contents of knorringite molecule (up to $30 \mathrm{~mol} \%$ ), suggest that their host rocks are diamondiferous. Support for this hypothesis comes from the high diamond potential of the investigated kimberlites at a comparatively low content of subcalcium $\mathrm{Cr}$-rich garnets, which are the indicators of diamonds in the ordinary Siberian and African kimberlites (Sobolev, 1971; Gurney et al., 1984), and from the high contents of the above-mentioned garnets extremely rich in $\mathrm{Cr}$, with their ratio of contents of $\mathrm{CaO}$ and $\mathrm{Cr}_{2} \mathrm{O}_{3}$ corresponding to the lherzolite trend. 


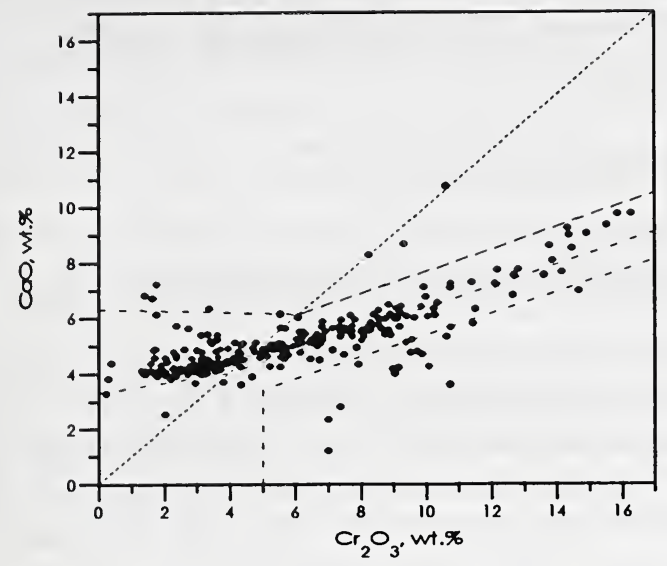

Fig. 1. Composition of the Snap Lake area (western part) pyropes, $\mathrm{CaO}$ vs $\mathrm{Cr}_{2} \mathrm{O}_{3}$ diagram $(n=317)$.

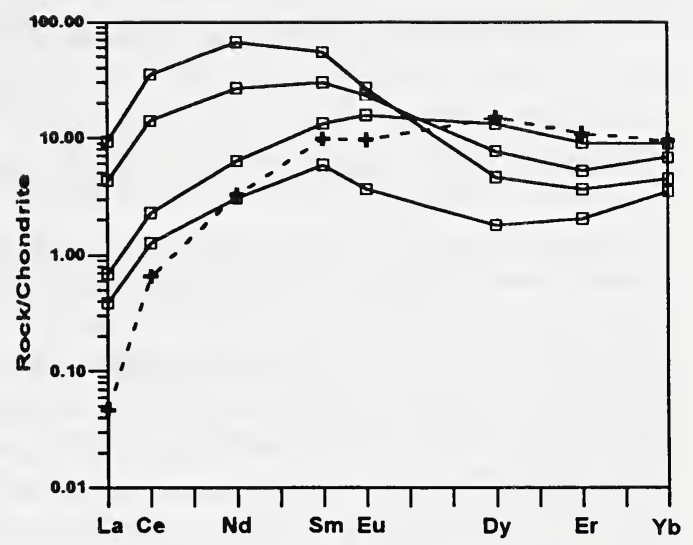

Fig.2. Representative REE patterns of the extremally high- $\mathrm{Cr}$ pyropes $\left(\mathrm{Cr}_{2} \mathrm{O}_{3}>12\right.$ wt.\%) (solid lines) and ordinary high- $\mathrm{Cr}$ pyrope $\left(\mathrm{Cr}_{2} \mathrm{O}_{3}=9.5 \mathrm{wt} . \%\right)$ (dashed line) of lherzolite paragenesis, Snap Lake area, western part.

\section{References}

Gurney, J.J., 1984, A correlation between garnets and diamonds: Kimberlite Occurrance and Origin: a basis for conceptual models in exploration, Glover, J.E., and Harris P.G., eds., Geol. Dept. and Univ. Ext. Univ. of W. Aust. Publ., N 8, p. 143-166.

Pokhilenko, N.P., McDonald, J.A., Melnyk, W., McCorquodale, J., 1995, Indicator minerals of CL25 kimberlite pipe, Slave Craton, North-West Territories, Canada: The 6th Intern. Kimberlite Conf., Ext.Abstr., Novosibirsk, Russia, p. 444-445.

Pokhilenko, N.P., McDonald, J.A., Melnyk, W., McCorquodale, J., Reimers, L.F., Sobolev, N.V., 1997, Indicator minerals from the CL-25 kimberlite pipe, Slave Craton, Northwest Territories, Canada: Proc. of the 6th Intern. Kimberlite Conf., Russian Geology and Geophysics, v. 38, p. 514-550.

Pokhilenko, N.P., Sobolev, N.V., Boyd, F,R., Pearson D.G., Shimizu, N., 1993, Megacrystalline pyrope peridotites in the lithosphere of the Siberian Platform: mineralogy, geochemical peculiarities and the problem of their origin: Geologiya i Geofizika, N 1, p. 71-84 (in Russian).

Shimizu, N., Richardson, S.H., 1987, Trace element abundance patterns of garnet inclusions in peridotite-suite diamonds: Geochim. Cosmochim. Acta, v.51, p. 755-758.

Skinner, E.M.W., Clement, C.R., 1979, Mineralogical classification of southern African kimberlites: Kimberlites, Diatremes and Diamonds: Their Geology, Petrology and Geochemistry, AGU, Washington, D.C., p. 129.

Sobolev, N.V., 1971, On mineralogical criteria of diamond content in kimberlites: Geologiya i Geofizika, N 3, p. 70-80 (in Russian).

Sobolev, N.V., Pokhilenko, N.P., Lavrent'ev, Yu.G., Usova, L.V., 1975, Characteristics of chromespinels in diamonds and kimberlites of Yakutia: Geologiya i Geofizika, N 11, p. 7-24 (in Russian). 